\title{
Copper effect on the protein composition of photosystem II
}

\author{
Inmaculada Yruela ${ }^{1, \star}$, Miguel Alfonso $^{1},{\text { Matilde } \text { Baró }^{2}}^{2}$ and Rafael Picorel ${ }^{1}$
}

${ }^{1}$ Estación Experimentad de Aula Dei (C.S.I.C.), Avda. de Montañana, 1005, Apdo. 202, E-50080 Zaragoza, Spain

${ }^{2}$ Estación Experimental del Zaidín (C.S.LC.), Profesor Albareda, 1, E-18008 Granada, Spain

*Corresponding author. e-mail: yruela@eead.csic.es

Abbreviations - Chl, chlorophyll; CP43 and CP47, antenna complexes of photosystem II: DCBQ, 2,6-dichlorobenzoquinone; EPR, electron paramagnetic resonance; Fm, maximum $\mathrm{Chl}$ a fluorescence; Fo, mínimum Chl a fluorescence; Fv, variable Chl a fluorescence; HEPES, N-2-hydroxyethylpiperazine-N'-2ethanesulphonie acid; MES, 2-(N-morpholino)ethanesulphonic acid; $\mathrm{P}_{680}$, primary electron donor of photosystem II reaction centre; PFD, photon flux density; Pheo, pheophytin; PS, photosystem; $Q_{A}$ and $Q_{B}$, primary and secondary plastoquinone electron acceptors of photosystem II; RC, reaction centre; SDS, sodium dodecyl sulphate; $\mathrm{Tyr}_{z}$ tyrosine 161 of the D1 polypeptide of photosystem II. 


\section{Abstract}

We provide data from in vitro experiment on the polypeptide composition, photosynthetic electron transport and oxygen evolution activity of intact photosystem II (PSII) preparations under $\mathrm{Cu}(\mathrm{II})$ toxicity conditions. Low $\mathrm{Cu}(\mathrm{II})$ concentrations $(\mathrm{Cu}(\mathrm{II})$ per PSII reaction centre unit $<230)$ that caused around $50 \%$ inhibition of variable chlorophyll a fluorescence and oxygen evolution activity did not affect the polypeptide composition of PSII. However, the extrinsic proteins of 33, 24 and $17 \mathrm{kDa}$ of the oxygen-evolving complex of PSII were removed when samples were treated with $300 \mu \mathrm{M} \mathrm{CuCl}_{2}(\mathrm{Cu}(\mathrm{II})$ per PSII reaction centre unit $=1400)$. The LHCII antenna complex and D1 protein of the reaction centre of PSII were not affected at these $\mathrm{Cu}(\mathrm{II})$ concentrations. The results indicated that the initial inhibition of the PSII electron transport and oxygen-evolving activity induced by the presence of toxic $\mathrm{Cu}(\mathrm{II})$ concentrations occurred before the damage of the oxygen-evolving complex. Indeed, more than $50 \%$ inhibition could be achieved in conditions where its protein composition and integrity was apparently preserved. 


\section{Introduction}

A significant part of the environmental pollution caused by modern human activities arises from the release of heavy metals into the environment. Some heavy metals such as $\mathrm{Cu}$ are essential as micronutrients, however, they are toxic at high concentrations for photosynthetic organisms (Clijsters and van Asche 1985, Maksymiec 1997). The copper-inhibitory effect on photosynthetic electron transport has been previously reported in planta, green alga and cyanobacteria. Extensive in vitro studies have shown that photosystem II (PSII) is more susceptible to copper toxicity (for review sea Droppa and Horváth 1990, Barón et al. 1995a) than photosystem I (PSI) (Ouzounidou et al. 1997). However, the precise location of the $\mathrm{Cu}(\mathrm{II})$-binding site on PSII and the underlying mechanisms of copper inhibition are still the subject of debate. Both the acceptor and donor side have been proposed as copper-inhibitory sites. On the PSII reducing side, the $Q_{B}$ binding site (Mohanty et al. 1989) and the Pheo-Fe- $Q_{A}$, domain (Yruela et al. 1991, 1992, 1993, 1996a) have been reported as the most sensitive sites for $\mathrm{Cu}$ (II) toxicity. In addition, the copper ion was shown to impair the function of the oxidising side (Cedeño-Maldonado and Swader 1972, Vierke and Struckmeier, 1977, Shioi et al. 1978a,b, Bohner et al. 1980, Samuelsson and Öquist 1980). Some authors (Schröder et al. 1994, Arellano et al. 1995) have suggested that the electron flow from tyrosine $\left(\mathrm{Tyr}_{\mathrm{z}}\right)$ to $\mathrm{P} 680^{+}$, is blocked at toxic Cu(II) concentrations. Králová et al. (1994) and Sersen et al. (1997) have proposed that $\mathrm{Cu}(\mathrm{II})$ interacts not only with $\mathrm{Tyr}_{z}$, but also with $\mathrm{Tyr}_{\mathrm{D}}$ on D2 protein. A possible direct interaction between copper and calcium at the oxidising side of PSII was also shown both in vitro (Sabat, 1996) and in vivo 
(Maksymiec and Baszynski, 1999). Additional effects of $\mathrm{Cu}(\mathrm{II})$ toxicity on both the donor side, affecting the Mn-cluster and the extrinsic proteins of the oxygen-evolving complex, and the acceptor side, interacting with the nonheme $\mathrm{Fe}^{2+}$ have been reported (Renger et al. 1993, Jegerschóld et al. 1995, 1999, Sersen et al. 1997). The interaction of $\mathrm{Cu}(\mathrm{II})$ toxicity with photoinhibitory and recovery proceses on PSII has been also investigated (Yruela et al. 1996b, Pätsikkä et al. 1998) demonstrating how $\mathrm{Cu}(\mathrm{II})$ enhances the adverse effects of light.

At present, most of the evidente for $\mathrm{Cu}(\mathrm{II})$ inhibition of the photosynthetic activity come from experiments in vitro. An extensive analysis of the literature reveals that the experimental conditions used in different publications differ significantly, particularly the copper concentration. The ratio between $\mathrm{Cu}(\mathrm{II})$ and the PSII reaction centre $(\mathrm{RC})$ unit $(\mathrm{Cu}(\mathrm{II}) / \mathrm{PSIIRC})$ was very variable depending on the techniques used in the measurements (i.e. oxygen evolution activity, fluorescence, flash-induced absorption spectroscopy, thermoluminescence, electron paramagnetic resonante (EPR), Fourier transform infrared (FTIR) spectroscopy, photoacoustic. This fact makes it difficult to compare and interpret the published results and makes it necessary to distinguish $\mathrm{Cu}(\mathrm{II})$ effects in vitro on PSII at low and high $\mathrm{Cu}(\mathrm{II})$ concentrations. It is also needs to be established which physiological effects of copper on photosynthesis in vivo result from inhibition of the electron transport on PSII.

It was shown in vivo that the decrease of the photochemical activity caused by $\mathrm{Cu}$ (II) was accompanied by an alteration of the structure and composition of the thylakoid membranes, which can influence the conformation and function of the photosystems (Baszynski et al. 1988, Ouzounidou et al. 1992, Lidon et al. 
1993). Baszynski and Krupa (1995) have proposed that those proceses induced by different heavy metals could involve either the destruction of the oxygen-evolving complex polypeptide composition or the interaction with ions necessary for proper functioning of the complexes such as $\mathrm{Mn}^{2+}, \mathrm{Ca}^{2+}$ and $\mathrm{Cl}^{-}$.

Considering that loss of oxygen-evolving complex extrinsic proteins induced by toxic $\mathrm{Cu}(\mathrm{II})$ concentrations is a mechanism that can operate in vivo and in vitro, we have addressed the question of how different $\mathrm{Cu}$ (II)/PSIIRC ratios affected both the PSII activity and the integrity of the oxygen-evolving complex, correlating the inactivation of the photosynthetic activity of PSII with changes in the polypeptide composition of PSII in the presence of $\mathrm{Cu}(\mathrm{II})$ from in vitro experiments.

\section{Materials and methods}

\section{Preparation of thylakoids and oxygenic PSII membranes}

Thylakoids and oxygenic PSII membranes were prepared from market spinach. Thylakoids were isolated as described by Nelson et al. (1970) with some modifications (Yruela et al. 1991). Tricine was used instead of N-2hydroxyethylpiperazine-N'-2-ethanesulphonie acid (HEPES)-NaOH to avoid chemical interference with $\mathrm{Cu}(\mathrm{II})$ (Renganathan and Bose, 1990). The thylakoid fraction was resuspended in $10 \mathrm{mM} \mathrm{NaCl}$ and $10 \mathrm{mM}$ HEPES$\mathrm{NaOH}(\mathrm{pH} 7.5)$ at a chlorophyll (Chl) concentration of $1.5 \mathrm{mg} \mathrm{ml}^{-1}$. Oxygenic PSII membranes were isolated by the method of Berthold et al. (1981) with the 
modification of Yruela et al. (1991). Samples were resuspended in $0.4 \mathrm{M}$ sucrose. $15 \mathrm{mM} \mathrm{NaCl}$. $5 \mathrm{mM} \mathrm{MgCl}_{2}$, and $50 \mathrm{mM}$ 2-(N-morpholino)ethancsulphonie acid (MES)- $\mathrm{NaOH}\left(\mathrm{pH} \mathrm{6.0)}\right.$. All purification steps performed at $4^{\circ} \mathrm{C}$ under dim light. Chl a concentration was determinad as described by Arnon (1949). Samples were frozen in liquid $\mathrm{N}_{2}$ and stored at $-80^{\circ} \mathrm{C}$ until use. Thylakoids and PSII membranes preparations exhibited oxygen evolution rates of 240 and $560 \mu \mathrm{mol} \mathrm{O}_{2} \mathrm{mg}^{-1} \mathrm{Chl} \mathrm{h}{ }^{-1}$, respectively, in the presence of $0.5 \mathrm{mM} \mathrm{2.6-}$ dichlorobenzoquinone (DCBQ) as artificial electron acceptor.

\section{Inhibition with $\mathrm{Cu}(\mathrm{II})$}

Thylakoids were resuspended at a final $\mathrm{Chl}$ concentration of $10-15 \mu \mathrm{g} \mathrm{ml}^{-1}$ in $10 \mathrm{mM} \mathrm{NaCl}$ and $25 \mathrm{mM}$ HEPES-NaOH (pH 7.5). PSIl membranes were resuspended at a final $\mathrm{Chl}$ concentration of $10 \mu \mathrm{g} \mathrm{ml}^{-1}$ in $10 \mathrm{mM} \mathrm{NaCl}$ and $25 \mathrm{mM}$ MES-NaOH (pH 6.5). Both types of samples were dark-adapted for 30 min at $4^{\circ} \mathrm{C}$ and incubated with $0-40 \mu \mathrm{M} \mathrm{CuCl}_{2}$, for 20 min at $4{ }^{\circ} \mathrm{C}$ with stirring before both fluorescence and oxygen evolution activity measurements.

\section{Oxygen evolution activity}

Oxygen evolution activity was measured with an oxygen electrode (Hansatech, Norfolk, UK) fitted with a water jacket thermostated at $25^{\circ} \mathrm{C}$. The standard assay medium consisted of $300 \mathrm{mM}$ sucrose, $10 \mathrm{mM} \mathrm{NaCl}$ and 25 $\mathrm{mM}$ MES-NaOH ( $\mathrm{pH}$ 6.5). DCBQ at a saturating concentration of $0.5 \mathrm{mM}$ was used as an artificial electron acceptor. Actinic light from two projector lamps 
placed on both sides of the electrode cuvette was filtered through $9.5 \mathrm{~cm}$ of water. The photon flux density (PFD) on the surface of each side of the sample cuvette was 2200,950 and $450 \mu \mathrm{mol} \mathrm{m} \mathrm{m}^{-2} \mathrm{~s}^{-1}$. DCBQ was disolved in ethanol and added just before measuring oxygen evolution activity. The ethanol concentration in the sample was less than $0.1 \%$.

\section{Chl a fluorescence induction}

Chl a fluorescence induction curves were recorded with a Hansatech photodiode detector connected to a digital storage oscilloscope. The sample was illuminated with a blue green actinic light from a $150 \mathrm{~W}$ tungsten lamp powered with a stabilised power supply and passing through $1 \mathrm{KG} 1$ and 3 KG3 Schott infrared filters plus a $620 \mathrm{~nm}$ low-pass filter. Light was passed through a Copal photographic shutter (2 ms opening time) and a Schölly fibre optic guide. The detector was protected by a $3 \mathrm{~mm}$ Schott RG 665 filter plus a $680 \mathrm{~nm}$ (10 $\mathrm{nm}$ bandpass) interference filter. The sample was kept stirred in an oxygen electrode cuvette and the PFD was $1000 \mu \mathrm{mol} \mathrm{m} \mathrm{m}^{-2} \mathrm{~s}^{-1}$ on the surface of the cuvette. This PFD was high enough to reduce the PSIl acceptor side in cells and thylakoids. PSIl fluorescence was monitored for $1.5 \mathrm{~s}$. All measurements were done at $24^{\circ} \mathrm{C}$.

\section{SDS-PAGE of PSII proteins and immunological techniques}

Samples at $150 \mu \mathrm{g} \mathrm{Chl} \mathrm{ml}^{-1}$ were treated with 5,50 and $300 \mu \mathrm{M} \mathrm{CuCl}_{2}$ for $20 \mathrm{~min}$ 
in the dark at $4^{\circ} \mathrm{C}$, centrifuged at $45000 \times g$ for 60 min and both the sediment and the supernatant were taken. SDS-PAGE of the different SDS-PAGE fractions was carried out basically as in Laemmli (1970). Equal amounts of PSII membranes and supernatant liquid were loaded onto the gel. We ran $12-22 \%$ acrylamide linear gradient gel containing $4 \mathrm{M}$ urea in the resolving gel. Samples were denatured at room temperature in sample buffer containing 50 $\mathrm{mM}$ Tris-OH ( $\mathrm{pH} 7.2$ ), $2 \%$ sodium dodecyl sulphate (SDS), $2 \mathrm{M}$ urea and 40 $\mathrm{mM}$ dithiothreitol. Gels were stained with Coomassie brilliant blue R-250. Protein concentration was determined by the method of Markwell et al. (1981). For immunoblotting, the same fractions obtained after $\mathrm{Cu}(\mathrm{II})$ treatment were analysed under denaturing conditions in continuous $15 \%$ acrylamide gels in the presence of $4 \mathrm{M}$ urea. Gels were transferred onto nitro-cellulose membranes with a BioRad transfer system and probed with antiserum against the LHCII antenna complex, the D1 and the $33 \mathrm{kDa}$ extrinsic protein of PSII raised in rabbit against the same proteins from spinach. Bands were revealed by the peroxidase method.

\section{Results}

The effect of $\mathrm{Cu}(\mathrm{II})$ concentration on the oxygen evolution activity of PSII membrane and thylakoid preparations was measured (Fig. 1). To calculate the $\mathrm{Cu}(\mathrm{II})$ per PSII reaction centre unit ( $\mathrm{Cu}(\mathrm{II}) / \mathrm{PSIIRC})$ ratio in PSII membranes we considered $250 \mathrm{Chl} / \mathrm{RC}$ (Berthold et al. 1981). The loss of activity by $\mathrm{Cu}(\mathrm{II})$ action was faster in PSII membranes compared to thylakoids. The finding was 
independent of the light intensity used during the measurements. A 50\% inactivation occurred with $\sim 7 \mu \mathrm{M}(\mathrm{Cu}(\mathrm{II}) / \mathrm{PSIIRC}=230)$ and $\sim 27 \mu \mathrm{M} \mathrm{CuCl}_{2}$, in PSII membranes and thylakoids, respectively. Such differences could be due to the fact that the $\mathrm{Cu}(\mathrm{II})$ binding site is more accessible in PSIl-enriched membranes than in thylakoids due to their different morphology and//or composition. The fact that similar inactivation was measured using high and low light intensities for each system supports this suggestion. According to that, we have also observed that the dependence of the incubation time on the $\mathrm{Cu}(\mathrm{II})$ inactivation differed between both type of samples (Fig. 2). The $\mathrm{Cu}(\mathrm{II})$ effect on chlorophyl a fluorescence parameters was also measured. Fig. 3A displays the Fo and Fv/Fm values of the thylakoid preparations incubated with variable amounts of $\mathrm{CuCl}_{2}$. Thylakoids with no addition of $\mathrm{Cu}(\mathrm{II})$ had a $\mathrm{Fv} / \mathrm{Fm}$ value of 0.79 which is indicative of an undamaged photosynthetic apparatus (Krause and Weis 1991). The variable fluorescence (Fv) and Fv/Fm (Fig. 3A, inset) was markedly reduced with increasing $\mathrm{Cu}(\mathrm{II})$ concentrations. However, the initial fluorescence (Fo) remained unchanged (data not shown). These data are in accordance with those reported by other authors (Shioi et al. 1978b, Bohner et al. 1980. Hsu and Lee 1988, Samson et al. 1988, Mohanty et al. 1989). A 50\% inhibition of $\mathrm{Fv}$ occurred in the presence of $\sim 20 \mu \mathrm{M} \mathrm{CuCl}_{2}$, whereas only 7 $30 \%$ of PSII are able to emit variable fluorescence after treatment with $40 \mu \mathrm{M}$ $\mathrm{CuCl}_{2}$. The results were consistent with those showed in Fig. 1. Addition of $\mathrm{Cu}(\mathrm{II})$ to a suspension of thylakoids pre-incubated with DCMU also decreased the $\mathrm{Fv}$ and $\mathrm{Fv} / \mathrm{Fm}$ values (Fig. 3B) in agreement with oxygen evolution measurements reported in previous works (Yruela et al. 1991, 1992). The slightly less inhibition in the presence of DCMU could be explained by $\mathrm{Cu}(\mathrm{II})$ having a 
high affinity for ligands with amine groups (Renganathan and Bose 1990) such as $\mathrm{DCMU}$, thus decreasing the active $\mathrm{Cu}(\mathrm{II})$-inhibitory concentration in the sample.

Fig. 4 shows the $\mathrm{Cu}(\mathrm{II})$ effect on the polypeptide composition of oxygen-evolving PSII preparations. Samples were incubated in the dark with 5, 50 and $300 \mu \mathrm{M}$ $\mathrm{CuCl}_{2}$ corresponding to a $\mathrm{Cu}(\mathrm{II}) / \mathrm{PSIIRC}$ ratio of 23,230 and 1400 , respectively. After $\mathrm{Cu}(\mathrm{II})$ treatment the PSII suspensions were centrifuged to separate the released proteins, and the pellet and supernatant fractions were analysed by SDS-PAGE. The results are representative of 3 independent experiments. Fig. $4 \mathrm{~A}$ shows that $50 \mu \mathrm{M} \mathrm{CuCl}_{2}(\mathrm{Cu}(\mathrm{II}) / \mathrm{PSIIRC}=230)$ does not remove any specific polypeptides of PSII, since the supernatant fractions obtained after $\mathrm{Cu}(\mathrm{II})$ incubation did not contain any free proteins (Fig. 4A, lanes 3 and 5). However, the highest concentration used, $300 \mu \mathrm{M} \mathrm{CuCl}_{2}(\mathrm{Cu}(\mathrm{II}) / \mathrm{PSIIRC}=$ 1400), caused the release of the 33, 24 and $17 \mathrm{kDa}$ polypeptides (Fig. 4A, lane 7), that could correspond to the extrinsic proteins that stabilise the oxygen-evolving complex and regulare its activity (Enami et al. 1989, 1991, Hankamer and Barber 1997). In these conditions, the loss of a proteins with apparent weight approximately of 43 and $47 \mathrm{kDa}$ were also observed (Fig. 4A, lane 6). The loss of these proteins differed from each other. The fact that the $43 \mathrm{kDa}$ protein lost due to $\mathrm{Cu}(\mathrm{II})$ action did not appear in the soluble phase (Fig. 4A, lane 7) could indicate that it is degraded during the treatment. In contrast, the $47 \mathrm{kDa}$ was lost by release to the soluble phase. Interaction between the 47 and 33 $\mathrm{kDa}$ proteins of the oxygen-evolving complex has been shown (Bricker et al. 1988, Hankamer and Barber 1997). Barón et al. (1995b) reported that $\mathrm{Cu}(\mathrm{II})$ stress in vivo had an effect on proteins associated with the oxygen-evolving 
complex. The immunoblot assays confirmed that the $33 \mathrm{kDa}$ protein released after incubation of the PSII preparations with $300 \mu \mathrm{M} \mathrm{CuCl}_{2}$ (Fig. $4 \mathrm{~A}$ and B, lane 7) corresponds to the extrinsic protein of the oxidising side of PSII, and show that this protein is only affected when PSII membranes are incubated with high $\mathrm{Cu}(\mathrm{II})$ concentrations. The effect of $\mathrm{Cu}(\mathrm{II})$ on the LHCII antenna complex and D1 protein of PSII was also analysed, being both unaffected even in the presence of the highest $\mathrm{Cu}(\mathrm{II})$ (Fig. 4B). These data indicate a specific effect of high $\mathrm{Cu}(\mathrm{II})$ concentration on the oxygen-evolving complex proteins. The oxygen evolution activity of the samples analysed by SDSPAGE was also measured (Table 1). The data indicated that a initial inhibition of photosynthesis as oxygen evolution activity occurs before any damage in the protein composition of the oxygen-evolving complex of PSII and at least $50 \%$ activity can be inhibited without affecting its integrity.

\section{Discussion}

The copper effect on the electron transport activity of PSII in vitro has been reported (sea reviews Droppa and Horváth 1990. Barón et al. 1995a). In those works, thylakoids, oxygenic and non-oxygenic PSIl-enriched membranes were used. Based on those investigations both the acceptor (Yruela et al. 1991, 1993, 1996a) and the donor sides (Schröder et al. 1994, Arellano et al. 1995, Horváth et al. 1998) of PSIl were proposed as the primary target of the $\mathrm{Cu}(\mathrm{II})$ inhibition.

The concentrations of $\mathrm{Cu}(\mathrm{II})$ and $\mathrm{Chl}$ in the inhibitory treatments reported in the literature differ depending on the techniques used for the 
measurements. concentrations of $\mathrm{Cu}(\mathrm{II})$ and $\mathrm{Chl}$ between 5 and $100 \mu \mathrm{M}$ and 6 and $115 \mu \mathrm{M}$, respectively, have been reported in oxygen evolution (Yruela et al. 1991. 1993). fluorescence (Arellano et al. 1995, Yruela et al. 1996a), flash-induced absorption spectroscopy (Schröder et al. 1994), thermoluminiscence (Horváth et al. 1998), FTIR spectroscopy (Szalontai et al. 1999) and photoacoustic (Boucher and Carpentier 1999) measurements. Those concentrations provided a variable $\mathrm{Cu}(\mathrm{II}) / \mathrm{PSIIRC}$ ratios from 210 to 700 , being difficult to compare the results from different experiments. Moreover, in EPR measurements (Jegerschöld et al. 1995, 1999) the amounts of $\mathrm{Cu}(\mathrm{II})$ and $\mathrm{Chl}$ were even higher, giving a $\mathrm{Cu}(\mathrm{II}) / \mathrm{PSI} \mathrm{RC}$ ratio from $1000-$ to 1400 -fold.

Leas effort has been done to study the copper effect on the polypeptide composition of PSII. However, it was reported that $\mathrm{Cu}(\mathrm{II})$ stress in vivo (Barón et al. 1995b, Baszynski and Krupa 1995) had an effect on proteins associated with the oxygen-evolving complex, disturbing the proper functioning of the $\mathrm{Mn}$ cluster, and the associated $\mathrm{Ca}^{2+}$ and $\mathrm{Cl}^{-}$ions. In addition, the in vitro dissociation of the oxygen-evolving complex proteins and displacement of the native cofactors $\left(\mathrm{Ca}^{2+}\right.$ and $\mathrm{Cl}^{-}$and $\left.\mathrm{Mn}\right)$ by heavy metals such as $\mathrm{Pb}(\mathrm{II})$ and $\mathrm{Zn}(\mathrm{II})$ (Rashid et al. 1994) were described. Studies with divalent ions as $\mathrm{Cu}(\mathrm{II}), \mathrm{Hg}(\mathrm{II})$ and $\mathrm{Pb}(\mathrm{II})$ also showed a donor side inhibition and possible recurrence of cycle electron transport around PSII under toxic conditions (Boucher and Carpentier, 1999).

In the present work, we have analysed the changes in isolated PSII membrane polypeptide composition in the presence of variable $\mathrm{Cu}(\mathrm{II})$ concentrations. The data indicated that low $\mathrm{Cu}(\mathrm{II})$ concentrations 
$(\mathrm{Cu}(\mathrm{II}) / \mathrm{PSIIRC}<230)$ that caused $-50 \%$ inhibition of the oxygen evolution activity did not affect the polypeptide composition of PSII. However, the 33, 24 and $17 \mathrm{kDa}$ extrinsic proteins of PSII can be removed by the effect of higher $\mathrm{Cu}(\mathrm{II})$ concentrations. It is well known that treatments with high salí concentrations (i.e.. $\mathrm{NaCl}$ ) affect the integrity of PSII, particularly by the loss of the 3 extrinsic proteins of the oxygen-evolving complex (Kuwabara and Murata 1983). We have obtained a similar effect at the highest $\mathrm{Cu}(\mathrm{II})$ concentrations, with $\mathrm{Cu}(\mathrm{II}) / \mathrm{PSIIRC}$ ratios higher than 230 . This degree of toxicity was used in EPR experiments and was demonstrated that $\mathrm{Cu}(\mathrm{II})$ provoked a loss of $\mathrm{Mn}$ and alteration of $\mathrm{Cyt} b_{559}$ potential and probable displacement of $\mathrm{Ca}^{2+}$ and $\mathrm{Cl}^{-}$(Jegerschöld et al. 1995). On the contrary, much lower $\mathrm{Cu}(\mathrm{II})$ concentration did not modify the ratio of Cyt $\mathrm{red}_{\text {d }} \mathrm{Cyt}_{\mathrm{ox}}$ in PSII membranes (Yruela et al. 1996b). On the other hand, the highest $\mathrm{Cu}(\mathrm{II})$ concentration caused the loss of 43 and $47 \mathrm{kDa}$ proteins. The CP43 antenna protein can be removed from the PSII core complex by treatment with either chaotropic agents such as potassium thiocyanate (Yamaguchi et al. 1988), or lithium perclorate (Ghanotakis et al. 1989) or by additional detergent treatments (Akabori et al. 1988). However, those treatments remove CP43 protein from PSII preparations without the removal of CP47 protein. The fact that high $\mathrm{Cu}(\mathrm{II})$ concentrations cause the loss of both antenna complexes indicate that its effect is stronger. It is known that histidyl residues are axial ligands for $\mathrm{Chl}$ molecules stabilizing pigment-protein complexes. Bricker (1990) has reported that histidyl residues are located near the predicted membrane surface of such complexes. Since $\mathrm{Cu}(\mathrm{II})$ has a high affinity for amine, triazole or imidazole nitrogen atoms and it is used in immobilised 
metal affinity chromatography (IMAC) for photosynthetic pigment-protein complexes purification (Sulkowski 1985, Vacha et al. 1995) we suggest that $\mathrm{Cu}(\mathrm{II})$ could interact with those amino acids destabilizing the 47 and $43 \mathrm{kDa}$ proteins.

The results reported here should be considered in the interpretation of published data and the design of new experiments on the location of the primary $\mathrm{Cu}(\mathrm{II})$-inhibitory site, distinguishing between $\mathrm{Cu}(\mathrm{II})$ effects in vitro on PSII at low and high $\mathrm{Cu}(\mathrm{II})$ concentrations.

Considering the data reported in this work, the presente of high $\mathrm{Cu}(\mathrm{II})$ concentrations can significantly modify the oxygen-evolving complex of PSII, dissociating the Mn cluster and associated cofactors. In these conditions, the donor side of PSII would be more exposed to $\mathrm{Cu}(\mathrm{II})$ action and the inactivation of electron transport at this region could occur. To gain further insight, it is necessary to know the changes in oxygen-evolving complex protein composition under $\mathrm{Cu}(\mathrm{II})$ toxicity in vivo, because such changes could be related to the physiological effects of this heavy metal on photosynthesis in vivo.

Acknowíedgements - The authors would like to thank María V. Ramiro for skilful technical assistance. This work was supported by the Dirección General de Investigación Científica y Técnica (Grant P1398-1632). 


\section{References}

Akabori K, Tsukamoto H, Tsukihara J, Nagatsuka T, Motokawa O, Toyoshima Y (1988) Disintegration and reconstitution of photosystem II reaction center core complex. I. Preparation and characterisation of three different types subcomplex. Biochim Biophys Acta 932: 345-357

Arellano JB, Lázaro JJ, López-Gorgé J, Barón M (1995) The donor side of PSII as the copper-inhibitory binding site. Photosynth Res 45: 127-134

Arnon DI (1949) Copper enzymes in isolated chloroplasts. Polyphenoloxidase in Beta vulgaris. Plant Physiol 24: 1-15

Barón M, Arellano JB, López-Gorgé J (1995a) Copper and photosystem II: A controversial relationship. Physiol Plant 94: 174-180

Barón M, Rahoutei J, Lázaro JJ, García-Luque I (1995b) PSII response to biotic and abiotic stress. In: Mathis P (ed) Photosynthesis: From Light to Biosphere, Vol. 4. Kluwer Academic Publishers, Dordrecht, pp 897-900

Baszynski T, Krupa $Z$ (1995) Some aspects of heavy metal toxicity towards photosynthetic apparatus - direct and indirect effects en light and dark reactions. Acta Physiol Plant 17: 177-191 
Baszynski T, Tukendorf A, Ruszkowska M, Skorzynska G, Maksymiec W (1988) Characteristics of the photosynthetic apparatus of copper non-tolerant spinach exposed to excess copper. J Plant Physiol 132: 708-713

Berthold DA, Babcock GT, Yocum CF (1981) A highly resolved oxygen-evolving photosystem II preparation from spinach thylakoid membrane: EPR and electron transport properties. FEBS Lett 134: $231-234$

Bohner H, Böhme H, Böger P (1980) Reciprocal formation of plastocyanin and cytochrome c-553 and the influence of cupric ion on photosynthetic electron transport. Biochim Biophys Acta 592: 103-112

Boucher $\mathrm{N}$, Carpentier $\mathrm{R}(1999) \mathrm{Hg}^{2+}, \mathrm{Cu}^{2+}$, and $\mathrm{Pb}^{2+}$-induced changes in photosystem II photochemical yield and energy storage in isolated thylakoid membranes: A study using simultaneous fluorescence and photoacoustic measurements. Photosynth Res 59: 167-174

Bricker TM (1990) The structure and function of CPa-1 and CPa-2 in photosystem II. Photosynth Res 24: 1-13

Bricker TM, Odom WR, Queirolo CB (1988) Close association of the $33 \mathrm{kDa}$ extrinsic protein with the apoprotein of CPa1 in photosystem II. FEBS Lett 231: $111-117$

Cedeño-Maldonado A, Swader JA (1972) The cupric ion as an inhibitor of 
photosynthetic electron transport in isolated chloroplasts. Plant Physiol 50: 698701

Clijsters H, van Asche $P$ (1985) Inhibition of photosysnthesis by heavy metals. Photosynth Res 7: 731-740

Droppa M, Horváth G (1990) The role of copper in photosynthesis. Crit Rev Plant Sci 9: 111-123

Enami I, Miyaoka T, Mochizuki Y, Shen J-R, Satoh K, Katoh S (1989) Nearest neighbor relationships among constituent proteins of oxygen-evolving photosystem II membranes: Binding and function of the extrinsic $33 \mathrm{kDa}$ protein. Biochim Biophys Acta 973: 35-40

Enami I, Kanelco M, Kitamura N, Koike H, Sonoike K, Inoue Y, Katoh S (1991) Total immobilization of the extrinsic $33 \mathrm{kDa}$ protein in spinach photosystem II membrane preparations. Protein stoichiometry and stabilization of oxygen evolution. Biochim Biophys Acta 1060: 224-232

Ghanotakis DF, de Paula JC, Demetriou DM, Bowlby NR, Petersen J, Babcock GT, Yocum CF (1989) Isolation and characterization of the $47 \mathrm{kDa}$ protein and the D1-D2-cytochrome b-559 complex. Biochim Biophys Acta 974: 4453 
Hankamer B, Barber J (1997) Structure and membrane organization of photosystem II in green plants. Annu Rev Plant Physiol Plant Mol Biol 48: 641-671

Horváth G, Arellano JB, Droppa M, Barón M (1998) Alterations in photosystem II electron transport as revealed by thermoluminescence of Cu-poisoned chloroplasts. Photosynth Res 57: 175-182

Hsu BD, Lee JY (1988) Toxic effects of copper en photosystem II of spinach chloroplasts. Plant Physiol 87: 116-119

Jegerschöld C, Arellano JB, Schröder WP, van Kan PJM, Barón M, Styring S (1995) $\mathrm{Cu}(\mathrm{II})$ inhibition of the electron transfer through photosystem II studied by EPR spectroscopy. Biochemistry 34: 12747-12754

Jegerschld C, MaecMillan F, Lubitz W. Rutherford AW (1999) Effects of copper and zinc ions on photosystem II studied by EPR spectroscopy. Biochemistry 38: 12439-12445

Králová K, Sersen F, Blahová M (1994) Effects of Cu(II) complexes on photosynthesis in spinach chloroplasts. Aqua (aryloxiacetato)copper (II) complexes. Gen Physiol Biophys 13: 483-491

Krause GH, Weis E (1991) Chlorophyll fluorescence and pbotosynthesis: The basics. Annu Rev Plant Mol Biol 42: 313-349 
Kuwabara T, Murata N (1983) Quantitative analysis of the inactivation of photosynthetic oxygen evolution and the release of polypeptides and manganese in the photosystem II particles of spinach chloroplasts. Plant Cell Physiol 24: 741-747

Laemmli UK (1970) Cleavage of structural proteins during the assembly of the head of bacteriophage T4. Nature 227: 680-685

Lidon FC, Ramalho JC, Henriques FS (1993) Copper inhibition of rice photosynthesis. J Plant Physiol 142: 12-17

Maksymiec W (1997) Effect of copper en cellular proceses in higher plants. Photosynthetica 34: 321-342

Maksymiec W, Baszynski T (1999) The role of $\mathrm{Ca}^{2+}$ ions in modulating changes induced in bean plants by an excess of $\mathrm{Cu}^{2+}$ ions. Chlorophyll fluorescence measurements. Physiol Plant 105: 562-568

Markwell M, Haas SM, Tolbert EN, Bieber LL (1981) Protein determination in membrane and lipoprotein samples: Manual and automated procedures. Methods Enzymol 72: 293-303

Mohanty N, Vass I, Demeter S (1989) Copper toxicity affects photosystem II electron transport at the secondary quinone acceptor $\left(Q_{B}\right)$. Plant Physiol 90: 175-179 
Nelson N, Drechsler Z, Neumann J (1970) Photophosphorylation in digitonin subcloroplast particles. J Biol Chem 245: 143-151

Ouzounidou G, Eleftheriou EP, Karataglis S (1992) Ecophysiological and ultraestructural effects of copper in Thlaspi ochroleucum (Cruciferae). Can J Bot 70: $947-957$

Ouzounidou G, Moustakas M, Strasser RJ (1997) Sites of action of copper in the photosynthetic apparatus of maize leaves: Kinetic analysis of Chlorophyll fluorecence, oxygen evolution, absorption changes and thermal dissipation as monitored by photoacoustic signals. Aust J Plant Physiol 24: 81-90

Pätsikkä E, Aro E-M, Tyystjárvi E (1998) Increase in the quantum yield of photoinhibition contributes to copper toxicity in vivo. Plant Physiol 117: 619-627

Rashid A, Camm EL, Ekramoddoullah KM (1994) Molecular mechanism of action of $\mathrm{Pb}^{2+}$ - and $\mathrm{Zn}^{2+}$ on water oxidising complex of photosystem II. FEBS Lett 350: $296-298$

Renganathan M, Bose S (1990) Inhibition of photosystem II activity by $\mathrm{Cu}(\mathrm{II})$ ion. Choice of buffer and reagent is critical. Photosynth Res 23: 95-99

Renger G, Gleiter HM, Haag E, Reifarth F (1993) Photosystem II: thermodynamics and kinetics of electron transport from $Q_{A}{ }^{-}$to $Q_{B}\left(Q_{B}{ }^{-}\right)$and deleterious effects of 
copper (II). Z Naturforsch 48c:34-240

Sabat SC (1996) Copper ion inhibition of electron transport activity in sodium chloride washed photosystem II particle is partially prevented by calcium ion. Z Naturforsch 51c: 179-184

Samson G. Morissette JC, Popovic R (1988) Copper quenching of the variable fluorescence in Dunaliella tertiolecta. New evidente for a copper inhibition effect on PSII photochemistry. Photochem Photobiol 84: 329-332

Samuelsson G, Öquist G (1980) Effects of copper chloride on photosynthetic electron transport and chlorophyll-protein complexes of Spinacea oleracea. Plant Cell Physiol 21: 445-454

Sersen K. Králová K, Bumbálová A, Svajlenova O (1997) The effect of Cu(II) ions bound with tridentate Schiff base ligands upon the photosynthetic apparatus. J Plant Physiol 151: 299-305

Schröder WP. Arellano JB, Bittner T, Barón M, Eckert H-J, Renger G (1994) Flashinduced absorption spectroscopy studies of copper interaction with photosystem II in higher plants. J Biol Chem 269: 32865-32870

Shioi Y. Tamai H. Sasa T (1978a) Effects of copper on photosynthetic electron transport systems in spinach chloroplasts. Plant Cell Physiol 19: 203-209 
Shioi Y. Tamai H, Sasa T (1978b) Inhibition of photosystem II in the Breen algae Ankistrodesmus falcatus by copper. Physiol Plant 44: 434-438

Sulkowski E (1985) Purification of proteins $b^{y}$ IMAC immobilized metal-affinity chromatography. Trends Biotechnol 3: 1-6

Szalontai B. Horváth LI, Debreczeny M, Droppa M, Horváth G (1999) Molecular rearragements of thylakoids after heavy metal poisoning, as seen by Fourier transform infrarred (FTIR) and electron spin resonance (ESR) spectroscopy. Photosynth Res 61: 241-252

Vacha F, Joseph DM, Durrant JR, Telfer A, Klug DR, Porter G, Barber J (1995) Photochemistry and spectroscopy of a five-chlorophyll reaction center of photosystem II isolated by using a Cu affinity column. Proc Natl Acad Sci USA 92: 2929-2933

Vierke G, Struckmeier P (1977) Binding of copper (II) to protein of the photosynthetic membrane and its correlation with inhibition of electron transport in class II chloroplasts of spinach. Z Naturforsch 32c: 605-610

Yamaguchi N, Takahashi Y, Satoh K (1988) Isolation and characterization of a photosystem II core complex depleted in the $43 \mathrm{kDa}$ chlorophyll-binding subunit. Plant Cell Physiol 29: 123-129 
Yruela I, Montoya G, Alonso PJ, Picorel R (1991) Identification of the pheophytin$\mathrm{Q}_{\mathrm{A}}-\mathrm{Fe}$ domain of the reducing side of the photosystem II as the $\mathrm{Cu}(\mathrm{II})$-inhibitory binding site. J Biol Chem 266: 22847-22850

Yruela I, Montoya G, Picorel R (1992) The inhibitory mechanism of Cu on the photosystem II electron transport from higher plants. Photosynth Res 33: 227233

Yruela I, Alfonso M, Ortiz de Zarate I, Montoya G. Picorel R (1993) Precise location of the Cu-inhibitory binding site in higher plant and bacterial photosynthetic reaction centers as probed by light-induced absorption changes. J Biol Chem 268: 1684-1689

Yruela I, Gatzen G, Picorel R, Holzwarth AR (1996a) Cu(II)-inhibitory effect on photosystem II from higher plants. A picosecond time-resolved fluorescence study. Biochemistry 35: 9469-9474

Yruela I, Pueyo JJ, Alonso PJ, Picorel R (1996b) Photoinhibition of photosystem II from higher plants: Effect of copper inhibition. J Biol Chem 271: 27408-27415 
Table 1. Effect of $\mathrm{Cu}(\mathrm{II})$ treatment on oxygen evolution activity and protein composition of oxygenic PSII-enriched membranes. The oxygen evolution activity was measured in PSII membranes particles $\left(10 \mu \mathrm{g} \mathrm{Chl} \mathrm{ml}^{-1}\right)$ in the presence of 0.5 mM DCBQ as artificial electron acceptor. Samples were dark-adaptad for $30 \mathrm{~min}$ at $4^{\circ} \mathrm{C}$ and subsequently incubated with $\mathrm{CuCl}_{2}$, for 20 min at $4^{\circ} \mathrm{C}$ before the measurements. The PFD on the surface of each side of the sample cuvette was 2 $200 \mu \mathrm{mol} \mathrm{m} \mathrm{m}^{-2} \mathrm{~s}^{-1}$. Protein composition was determined by SDS-PAGE $(12-22 \%)$ acrylamide linear gradient). PSII membrane particles were incubated with $\mathrm{CuCl}_{2}$ for $20 \mathrm{~min}$ in the dark at $4^{\circ} \mathrm{C}$. Gels were stained by Coomassie brilliant blue R-250. Values represent means of 3 independent experiments.

\begin{tabular}{lccc} 
Samples & $\mathrm{Cu}(\mathrm{II}) / \mathrm{PSIIRC}$ & $\begin{array}{c}\text { Oxygen evolution } \\
\left(\mu \mathrm{mol} \mathrm{O} \mathrm{mg}^{-1} \mathrm{Chl} \mathrm{h}^{-1}\right)\end{array}$ & Protein released \\
\hline Non-treated & - & $560 \pm 15(100 \%)$ & \\
$\mathrm{Cu}(\mathrm{II})$-treated & 23 & $454 \pm 7(81 \%)$ & \\
$5 \mu \mathrm{M} \mathrm{CuCl} 2$ & 230 & $268 \pm 5(48 \%)$ & $33,24,17 \mathrm{kDa}$ \\
$50 \mu \mathrm{M} \mathrm{CuCl}_{2}$ & 1400 & $78 \pm 11(14 \%)$ & \\
$300 \mu \mathrm{M} \mathrm{CuCl}_{2}$ & & & \\
\hline
\end{tabular}




\section{Figure Legends}

Fig. 1. Effect of increasing amounts of $\mathrm{Cu}(\mathrm{II})$ on oxygen evolution of PSIl membranes $\left(10 \mu \mathrm{g} \mathrm{ml}^{-1}\right)(\bullet, \boldsymbol{\Delta}, \mathbf{\square})$ and thylakoids $(15 \mu \mathrm{g} \mathrm{ml-})(\mathrm{O}, \Delta, \square)$. The activity was measured in the presence of $0.5 \mathrm{mM} \mathrm{DCBQ}$ as artificial electron acceptor. Samples were darkadapted for 30 min at $4{ }^{\circ} \mathrm{C}$ and subsequently incubated with $\mathrm{CuCl}_{2}$ for 20 min at $4^{\circ} \mathrm{C}$ before the measurements. The PFD on the surface of each side of the sample cuvette during the oxygen evolution activity measurements was $2200(\bullet, 0)$, $950(\boldsymbol{\Delta}, \Delta)$ and $450(\boldsymbol{\square}, \square) \mu \mathrm{mol} \mathrm{m} \mathrm{m}^{-2} \mathrm{~s}^{-1}$. Values represent means +SE $(\mathrm{n}=4)$.

Fig. 2. Dependence on incubation time of the oxygen evolution activity of thylakoids (0) and PSIl membranes (0) treated with 15 and $5.5 \mu \mathrm{M} \mathrm{CuCl}$, respectively. The activities were measured in the presence of $0.5 \mathrm{mM} \mathrm{DCBQ}$ as an artificial electron acceptor. The PFD on the surface of each side of the sample cuvette during the oxygen evolution activity measurements was $2200 \mu \mathrm{mol} \mathrm{m} \mathrm{m}^{-2} \mathrm{~s}^{-1}$. Chl concentrations were 15 and $10 \mu \mathrm{g} \mathrm{ml}^{-1}$ for thylakoids and PSII membranes, respectively. Values represent means $\pm S E(n=4)$.

Fig. 3. Relative values of Fv and Fv/Fm chlorophyll a fluorescence parameters in thylakoids treated with different $\mathrm{CuCl}_{2}$ concentrations in the absence $(\mathrm{A})$ and presence (B) of $0.5 \mu \mathrm{M}$ DCMU. Samples at $10 \mu \mathrm{g} \mathrm{m}^{-1} \mathrm{Chl}$ were dark-adapted for 30 $\min$ at $4^{\circ} \mathrm{C}$ and subsequently incubated with $\mathrm{CuCl}_{2}$ for $20 \mathrm{~min}$ at $4^{\circ} \mathrm{C}$ before the measurements in the absence of DCMU. The DCMU was added immediately before 
the measurements. The PFD during the fluorescence measurements was $1000 \mu \mathrm{mol}$ $m^{-2} s^{-1}$. Values represent means $\pm S E(n=4)$.

Fig. 4. (A) SDS-PAGE and (B) immunoblots with antiserum anti-LHCII antenna complex, anti-33 kDa extrinsic protein and anti-D1 reaction centre subunit of PSII membrane preparations incubated with $\mathrm{CuCl}_{2}$ in the dark for 20 min at $4^{\circ} \mathrm{C}$ (lanes $1,2,4,6)$ and supernatant fraction obtained by centrifugation of PSII membranes after $\mathrm{Cu}(\mathrm{II})$ treatment (lanes 3, 5, 7). Lane 1: control; lanes 2 and 3: $5 \mu \mathrm{M}(\mathrm{Cu}(\mathrm{II})$ /PSIIRC=23); lanes 4 and 5: $50 \mu \mathrm{M}(\mathrm{Cu}(\mathrm{II}) / \mathrm{PSIIRC}$ lanes 6 and 7: $300 \mu \mathrm{M}$ $\mathrm{Cu}(\mathrm{II}) / \mathrm{PSIIRC}=1400)$. Values are the average of 3 independent experiments. 


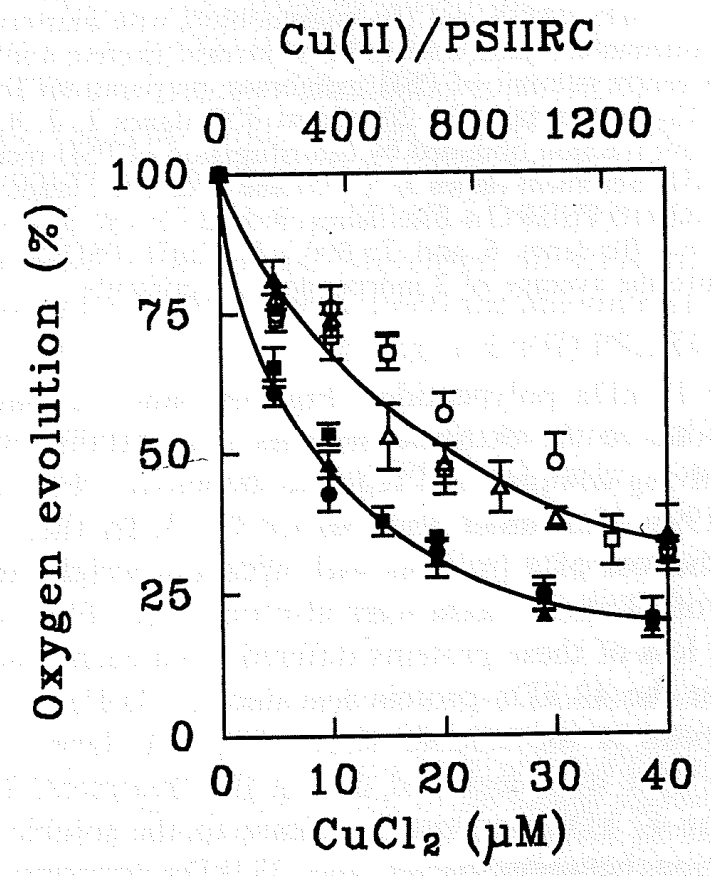

Fig. 1 


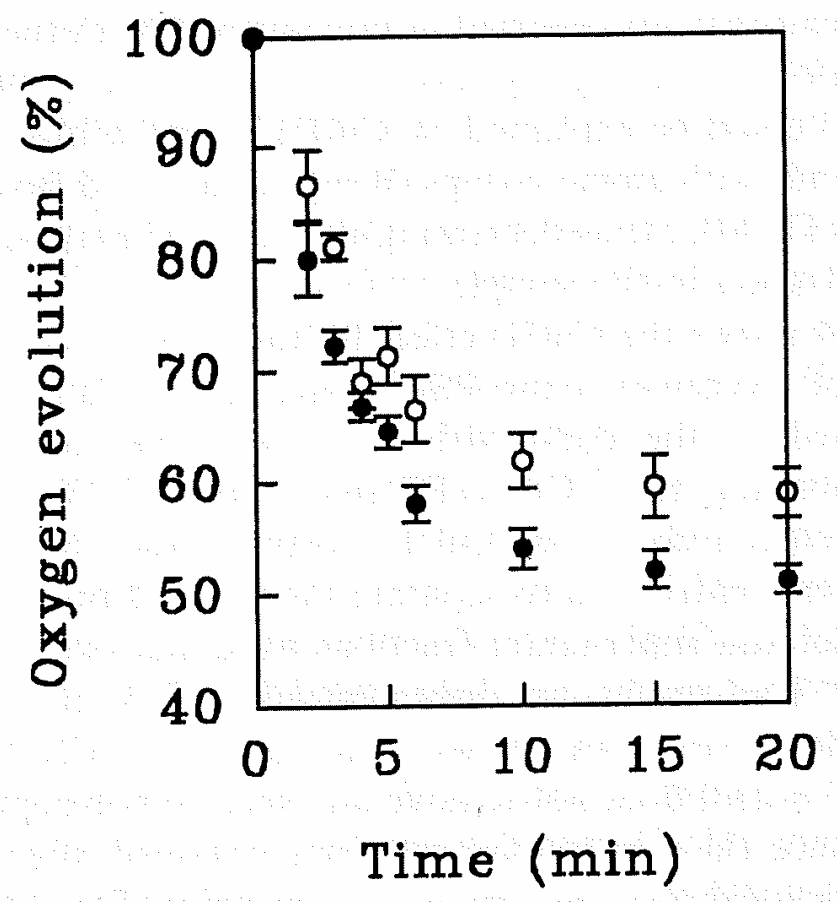

Fig. 2 


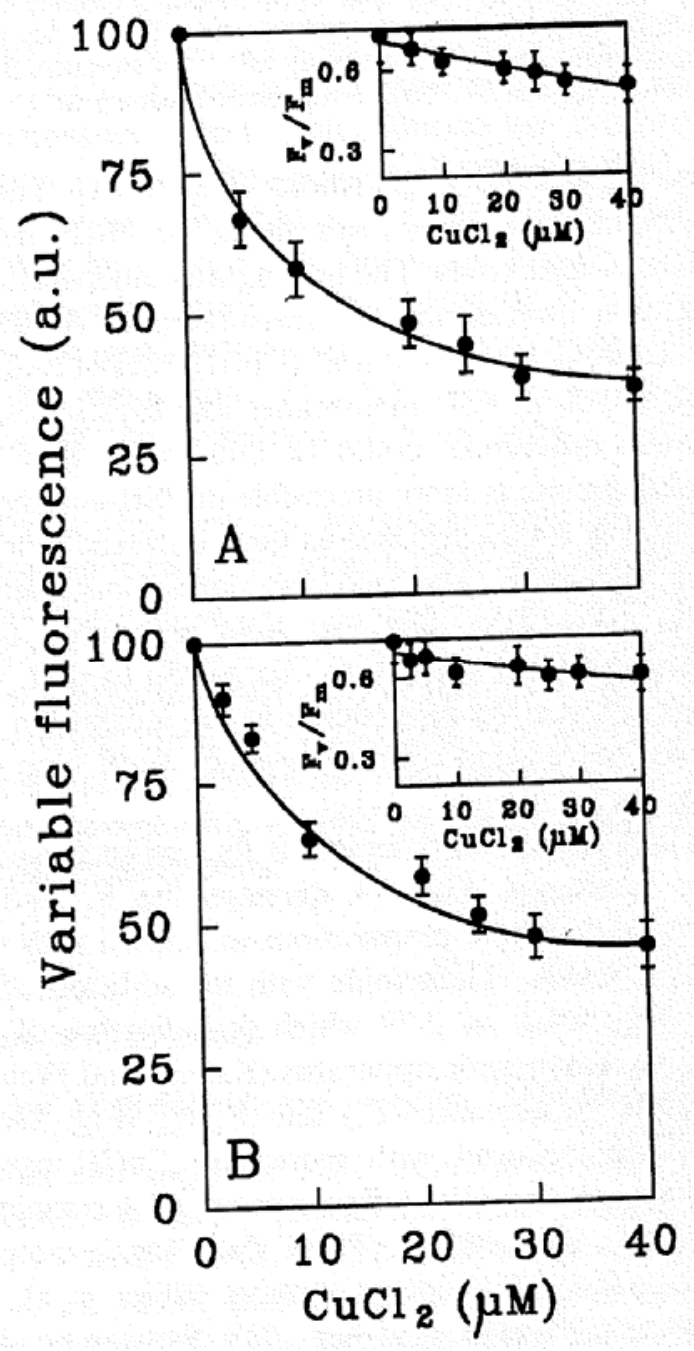

Fig. 3 
A

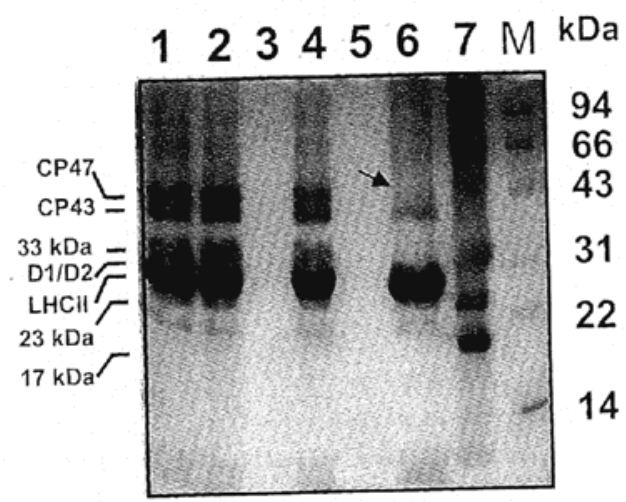

B

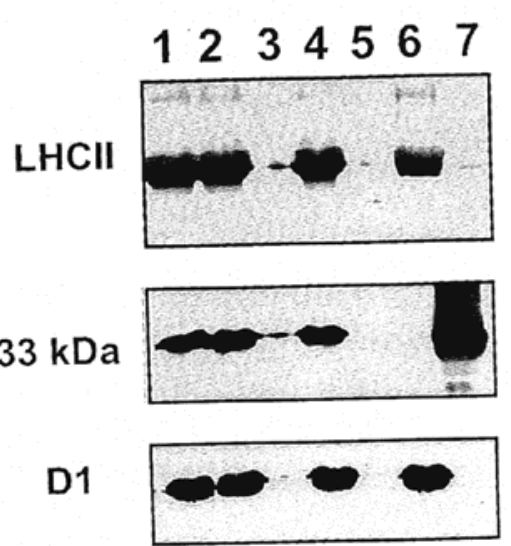

Fig. 4 